\title{
PERBANDINGAN KELARUTAN KALSIUM DAN MAGNESIUM EMAIL GIGI TERHADAP MINUMAN BERKARBONASI DAN ISOTONIK
}

\author{
Nurwiyana Abdullah, Syamsuddin Abubakar
}

\begin{abstract}
ABSTRAK
Email gigi terdiri dari 92-93\% zat anorganik, 1-2\% zat organik dan 3-4\% air. Zat anorganik yang utama berupa hidroksiapatit $\left[\mathrm{Ca}_{10}\left(\mathrm{PO}_{4}\right)_{6}(\mathrm{OH})_{2}\right]$ sekitar $90-92 \%$ dari volumenya yang tersusun atas komponen-komponen kalsium dan magnesium. Kehilangan ion kalsium dan magnesium karena demineralisasi sangat mempengaruhi kerusakan email gigi. Demineralisasi terjadi karena adanya paparan asam dari makanan atau minuman yang dalam waktu lama di dalam mulut menyebabkan $\mathrm{pH}$ rongga mulut menjadi asam. Penelitian ini bertujuan untuk mengetahui perbandingan minuman berkarbonasi dan minuman isotonik terhadap kelarutan kalsium dan magnesium setelah perendaman gigi secara AAS (Atomic Absorption Spectrophotometer). Penelitian ini merupakan eksperimen laboratorium (spectrophotometer) dengan desain penelitian time series yang menggunakan 4 gigi permanen manusia post ekstraksi sebagai subyek penelitian. Keempat gigi tersebut dimasukkan ke dalam minuman karbonasi dan minuman isotonik lalu diukur kelarutan kalsium dan magnesium email gigi tersebut selama 30 menit sampai pada hari keenam dangan menggunakan spektrophotometer. Hasil penelitian menunjukkan bahwa ion kalsium lebih banyak mengalami kelarutan daripada magnesium dari kedua minuman tersebut.
\end{abstract}

Kata kunci : Minuman karbonasi, Minuman isotonik, Kalsium dan Magnesium

\section{PENDAHULUAN}

Email gigi merupakan suatu jaringan keras yang mengalami proses mineralisasi yang sangat tinggi yang menutupi seluruh mahkota gigi (Achmad M.H, 2015: 7). Email mengandung zat anorganik dalam jumlah yang besar, sehingga merupakan bagian yang paling keras pada tubuh manusia. Namun karena letaknya yang paling luar, maka email dipengaruhi oleh faktor positif maupun negatif dalam rongga mulut. Faktor yang berpengaruh pada kerusakan email salah satunya adalah keasaman makanan dan minuman.

$$
\text { Di era modern seperti sekarang, }
$$

banyak produk-produk yang menawarkan makanan dan minuman secara instant. Kebiasaan mengkonsumsi makanan dan minuman yang instant telah meningkat dari frekuensi maupun jumlahnya. Selain rasanya yang memiliki sensasi nikmat dan juga segar, tanpa disadari bahwa semua itu memiliki zatzat yang dapat merusak permukaan gigi misalnya minuman bersoda. Tuntutan pekerjaan yang sibuk untuk memenuhi kebutuhannya, manusia dihadapkan pada keadaan yang sulit dihindari untuk memilih makanan dan minuman yang serba instan salah satunya adalah minuman bersoda maupun isotonik yang bersifat merusak kesehatan khususnya kesehatan gigi (Nisha, 2014).

Di Indonesia sendiri minuman bersoda bukan lagi hal yang luar biasa, minuman bersoda merupakan minuman ringan yang memiliki sensasi menggigit ketika dikonsumsi. Awalnya minuman bersoda sangat dihindari oleh mereka karena berpotensi untuk membuat tubuh menjadi gemuk akibat dari kandungan gula di dalam minuman tersebut. Tapi, belakangan diketahui bahwa masih ada 
bahaya lain yang dapat terjadi, yakni kerusakan pada email gigi. Menurut para ahli, penyebab utamanya adalah adanya kandungan asam sitrat dalam minuman bersoda. Asam sitrat ini merupakan asam organik yang dapat melarutkan kalsium maupun fosfat pada email gigi yang merupakan proses awal terjadinya kerusakan jaringan keras gigi, salah satunya adalah erosi gigi (Ruslan, 2014).

Produksi berbagai jenis minuman ringan yang dipasarkan dan dikonsumsi secara global diketahui secara pasti dapat menyebabkan demineralisasi enamel yang secara langsung dikenal sebagai erosi gigi (Prasetyo E.A cit Soebekti, 2005). Berdasarkan hasil penelitian Jenssdottir T (2004), prevalensi terjadinya erosi gigi diakibatkan karena tingginya frekuensi dalam mengkonsumsi minuman yang berpotensi menimbulkan erosif ringan dengan nilai $\mathrm{pH}$ yang rendah merupakan satu-satunya faktor risiko yang dapat diidentifikasi untuk menimbulkan terjadinya erosi gigi.

Penelitian membuktikan bahwa minuman isotonik (sports drink) dan minuman energi bersifat lebih erosif daripada minuman soda karena pengaruh asam di dalam minuman tersebut (Fraunhover J.A, 2004). Kebanyakan dari minuman ringan, termasuk minuman isotonik mengandung beberapa jenis asam, seperti phosphoric acid, asam sitrat, malic acid dan tartaric acid (Bamise C.T, 2007). Beberapa penelitian juga membuktikan bahwa minuman isotonik (sports drinks) biasanya diminum secara perlahan, sehingga sisa residu minuman dapat tertinggal dalam rongga mulut untuk beberapa waktu. Hal ini dapat mempengaruhi kesehatan gigi, karena minuman seperti minuman isotonik (sports drinks) mempunyai $\mathrm{pH}$ yang rendah dan dapat menyebabkan erosi gigi (Mettler S, 2006).

Dari hasil penelitian ini nantinya akan terlihat seberapa besar pengaruh perendaman gigi terhadap kehilangan kandungan kalsium dan magnesium email gigi yang merupakan tanda awal terjadinya erosi pada gigi sehingga ada kemungkinan terjadinya hypersensitif dentin. Oleh sebab itu, penelitian ini penting untuk dilakukan sebab peneliti tertarik untuk melakukan penelitian tentang perbedaan minuman berkarbonasi dan minuman isotonik terhadap kelarutan kalsium dan magnesium setelah perendaman gigi secara AAS (Atomic Absorption Spectrophotometer).

\section{METODE PENELITIAN}

Penelitian ini bersifat eksperimen laboratorium dengan desain penelitian time series. Untuk mengetahui perbandingan minuman berkarbonasi dan minuman isotonik terhadap kelarutan kalsium dan magnesium setelah perendaman gigi secara AAS (Atomic Absorption Spectrophotometer).

Subyek penelitian adalah 4 gigi permanen manusia dengan waktu 1 minggu post ekstraksi yang masing-masing dimasukkan ke dalam minuman berkarbonasi (Coca Cola) dan minuman isotonik (Pocari Sweat), dengan kriteria tidak karies dan tidak ada restorasi. Alat yang digunakan dalam penelitian adalah AAS (Atomic Absorption Spectrophotometer) untuk memeriksa kelarutan kalsium dan magnesium, gelas kimia, tabung reaksi, botol berwarna gelap, pinset, spoit 


\section{HASIL PENELITIAN}

Penelitian ini dilakukan di Balai Besar

Laboratorium Makassar dengan menggunakan

Atomic Absorption Spectrophotometer sebagai alat untuk memeriksa kelarutan kalsium dan magnesium email gigi setelah perendaman 4 gigi post ekstraksi dalam minuman ringan (coca cola dan pocari sweat).

Sebelum dilakukan perendaman, terlebih dahulu keempat gigi diperiksa jumlah kalsium dan magnesiumny. hasil pengukuran kadar kasium dan magnesium dari keempat gigi sebagai berikut:

Tabel 1. Distribusi Jumlah Kalsium dan Magnesium Email Gigi Sebelum Perendaman

\begin{tabular}{ccc}
\hline Kode Sampel & Jumlah Kalsium & Jumlah Magnesium \\
\hline G1 & $225.613,03 \mathrm{mg} / \mathrm{L}$ & $5.990,82 \mathrm{mg} / \mathrm{L}$ \\
G2 & $217.743,12 \mathrm{mg} / \mathrm{L}$ & $5.683,41 \mathrm{mg} / \mathrm{L}$ \\
G3 & $238.361,62 \mathrm{mg} / \mathrm{L}$ & $5.298,89 \mathrm{mg} / \mathrm{L}$ \\
G4 & $217.572,29 \mathrm{mg} / \mathrm{L}$ & $5.308,10 \mathrm{mg} / \mathrm{L}$ \\
\hline
\end{tabular}

Berdasarkan tabel diatas diketahui bahwa sampel belum diberikan perlakuan. Dilakukan perhitungan jumlah kaslium dan magnesium sebelum dilakukan perendaman kedalam kedua minuman. Terlihat bahwa jumlah kalsium pada sampel G1 sebesar 225.613,03 $\mathrm{mg} / \mathrm{L}$ dan jumlah magnesium sebesar 5.990,82 mg/L, untuk sampel G2 jumlah kalsium sebesar $217.743,12 \mathrm{mg} / \mathrm{L}$ dan jumlah magnesium sebesar $5.683,41 \mathrm{mg} / \mathrm{L}$, untuk sampel G3 jumlah kalsium sebesar 238.361,62 mg/L dan jumlah magnesium sebesar 5.298,89 mg/L, sedangkan untuk sampel G4 jumlah kalsium sebesar 217.572,29 $\mathrm{mg} / \mathrm{L}$ dan jumlah magnesium sebesar 5.308,10 $\mathrm{mg} / \mathrm{L}$. Terlebih dahulu keempat gigi tersebut direndam dalam minuman ringan selama 30 menit sampai pada hari ke enam.

Pada hari ke tujuh, gigi yang telah direndam dibawa kembali ke laboratorium untuk dilihat jumlah kelarutan kalsium dan magnesium email gigi setelah direndam dalam minuman ringan. Maka diperoleh data tabel sebagai berikut:

Tabel 2. Distribusi Jumlah Kalsium dan Magnesium Email Gigi Setelah Perendaman

\begin{tabular}{|c|c|c|c|c|}
\hline $\begin{array}{l}\text { Kode } \\
\text { Sampel }\end{array}$ & Jenis Minuman & $\begin{array}{c}\text { Waktu } \\
\text { Perendaman }\end{array}$ & Jumlah Kalsium & $\begin{array}{c}\text { Jumlah } \\
\text { Magnesium }\end{array}$ \\
\hline G1 & Coca Cola & $\begin{array}{l}30 \text { menit sampai } \\
\text { hari keenam }\end{array}$ & $225.557,81 \mathrm{mg} / \mathrm{L}$ & $5.978,36 \mathrm{mg} / \mathrm{L}$ \\
\hline G2 & Pocari Sweat & $\begin{array}{l}30 \text { menit sampai } \\
\text { hari keenam }\end{array}$ & $217.706,28 \mathrm{mg} / \mathrm{L}$ & $5.674,64 \mathrm{mg} / \mathrm{L}$ \\
\hline G3 & $\begin{array}{c}\text { Coca Cola => } \\
\text { Aquades }\end{array}$ & $\begin{array}{c}30 \text { menit }=>15 \\
\text { menit sampai hari } \\
\text { keenam }\end{array}$ & $238.312,19 \mathrm{mg} / \mathrm{L}$ & $5.288 \mathrm{mg} / \mathrm{L}$ \\
\hline G4 & $\begin{array}{c}\text { Pocari Sweat }=> \\
\text { Aquades }\end{array}$ & $\begin{array}{c}30 \text { menit }=>15 \\
\text { menit sampai hari } \\
\text { keenam }\end{array}$ & $217.537,69 \mathrm{mg} / \mathrm{L}$ & $5.300,82 \mathrm{mg} / \mathrm{L}$ \\
\hline
\end{tabular}


Pada tabel diatas, dapat dilihat bahwa keempat gigi telah direndam dalam minuman ringan. Diketahui bahwa G1 yang direndam dalam coca cola selama 30 menit sampai pada hari keenam mengalami penurunan jumlah kalsium sebesar 225.557,81 $\mathrm{mg} / \mathrm{L}$ dan magnesium sebesar 5.978,36 mg/L, untuk G2 yang direndam dalam pocari sweat selama 30 menit sampai pada hari keenam mengalami penurunan jumlah kalsium sebesar 217.706,28 $\mathrm{mg} / \mathrm{L}$ dan magnesium sebesar $5.674,64 \mathrm{mg} / \mathrm{L}$, sedangkan untuk G3 yang terlebih dahulu direndam dalam coca cola selama 30 menit setelah itu direndam lagi dalam aquades selama 15 menit mengalami penurunan jumlah kalsium sebesar 238.312,19 $\mathrm{mg} / \mathrm{L}$ dan magnesium sebesar $5.288 \mathrm{mg} / \mathrm{L}$, dan untuk G4 yang juga terlebih dahulu direndam dalam pocari sweat selama 30 menit setelah itu direndam kembali dalam aquades selama 15 menit mengalami penurunan jumlah kalsium sebesar 217.537,69 mg/L dan magnesium sebesar 5.300,82 mg/L.

Tabel 3. Selisih Perbandingan Kalsium dan Magnesium Email Gigi

\begin{tabular}{|c|c|c|c|c|c|c|c|}
\hline \multirow{2}{*}{$\begin{array}{c}\text { Kode } \\
\text { Sampel }\end{array}$} & \multirow[b]{2}{*}{$\begin{array}{c}\text { Waktu } \\
\text { Perendaman }\end{array}$} & \multicolumn{2}{|c|}{ Jumlah Kalsium } & \multicolumn{2}{|c|}{ Jumlah Magnesium } & \multicolumn{2}{|c|}{ Jumlah Kelarutan } \\
\hline & & $\begin{array}{l}\text { Sebelum } \\
\text { Direndam }\end{array}$ & $\begin{array}{c}\text { Setelah } \\
\text { Direndam }\end{array}$ & $\begin{array}{l}\text { Sebelum } \\
\text { Direndam }\end{array}$ & $\begin{array}{c}\text { Setelah } \\
\text { Direndam }\end{array}$ & $\mathrm{Ca}$ & Mg \\
\hline G1 & $\begin{array}{l}30 \text { menit } \\
\text { sampai hari } \\
\text { keenam }\end{array}$ & $\begin{array}{c}225.613,03 \\
\mathrm{mg} / \mathrm{L}\end{array}$ & $\begin{array}{c}225.557,81 \\
\mathrm{mg} / \mathrm{L}\end{array}$ & $\begin{array}{c}5.990,82 \\
\mathrm{mg} / \mathrm{L}\end{array}$ & $\begin{array}{c}5.978,36 \\
\mathrm{mg} / \mathrm{L}\end{array}$ & $\begin{array}{l}55,22 \\
\mathrm{mg} / \mathrm{L}\end{array}$ & $\begin{array}{l}12,46 \\
\mathrm{mg} / \mathrm{L}\end{array}$ \\
\hline G2 & $\begin{array}{c}30 \text { menit } \\
\text { sampai hari } \\
\text { keenam }\end{array}$ & $\begin{array}{c}217.743,12 \\
\mathrm{mg} / \mathrm{L}\end{array}$ & $\begin{array}{c}217.706,28 \\
\mathrm{mg} / \mathrm{L}\end{array}$ & $\begin{array}{c}5.683,41 \\
\mathrm{mg} / \mathrm{L}\end{array}$ & $\begin{array}{c}5.674,64 \\
\mathrm{mg} / \mathrm{L}\end{array}$ & $\begin{array}{l}36,84 \\
\mathrm{mg} / \mathrm{L}\end{array}$ & $\begin{array}{l}8,77 \\
\mathrm{mg} / \mathrm{L}\end{array}$ \\
\hline G3 & $\begin{array}{c}30 \text { menit => } 15 \\
\text { menit sampai } \\
\text { hari keenam }\end{array}$ & $\begin{array}{c}238.361,62 \\
\mathrm{mg} / \mathrm{L}\end{array}$ & $\begin{array}{c}238.312,19 \\
\mathrm{mg} / \mathrm{L}\end{array}$ & $\begin{array}{c}5.298,89 \\
\mathrm{mg} / \mathrm{L}\end{array}$ & $5.288 \mathrm{mg} / \mathrm{L}$ & $\begin{array}{l}49,43 \\
\mathrm{mg} / \mathrm{L}\end{array}$ & $\begin{array}{l}10,89 \\
\mathrm{mg} / \mathrm{L}\end{array}$ \\
\hline G4 & $\begin{array}{c}30 \text { menit }=>15 \\
\text { menit sampai } \\
\text { hari keenam }\end{array}$ & $\begin{array}{c}217.572,29 \\
\mathrm{mg} / \mathrm{L}\end{array}$ & $\begin{array}{c}217.537,69 \\
\mathrm{mg} / \mathrm{L}\end{array}$ & $\begin{array}{c}5.308,10 \\
\mathrm{mg} / \mathrm{L}\end{array}$ & $\begin{array}{c}5.300,82 \\
\mathrm{mg} / \mathrm{L}\end{array}$ & $\begin{array}{l}34,6 \\
\mathrm{mg} / \mathrm{L}\end{array}$ & $\begin{array}{r}7,28 \\
\mathrm{mg} / \mathrm{L}\end{array}$ \\
\hline
\end{tabular}

Berdasarkan tabel diatas, dapat dilihat

selisih perbandingan kelarutan kalsium dan magnesium email gigi. Untuk G1 yang direndam dalam coca cola selama 30 menit sampai pada hari keenam mengalami kelarutan kalsium sebesar 55,22 $\mathrm{mg} / \mathrm{L}$ sedangkan kelarutan magnesium sebesar 12,46 mg/L, untuk G2 yang direndam dalam pocari sweat selama 30 menit sampai pada hari keenam mengalami kelarutan kalsium sebesar 36,84 $\mathrm{mg} / \mathrm{L}$ sedangkan kelarutan magnesium sebesar $8,77 \mathrm{mg} / \mathrm{L}$, sedangkan G3 yang terlebih dahulu direndam dalam coca cola selama 30 menit setelah itu direndam lagi dalam aquades selama 15 menit mengalami kelarutan kalsium sebesar 49,43 mg/L sedangkan kelarutan magnesium sebesar 10,89 mg/L, dan untuk G4 yang juga terlebih dahulu direndam dalam pocari sweat selama 30 menit setelah itu direndam kembali dalam aquades selama 15 menit mengalami kelarutan kalsium sebesar $34,6 \mathrm{mg} / \mathrm{L}$ sedangkan kelarutan magnesium sebesar 7,28 $\mathrm{mg} / \mathrm{L}$. 


\section{PEMBAHASAN}

Telah dilakukan penelitian mengenai perbandingan minuman karbonasi (coca cola) dengan minuman isotonik (pocari sweat) terhadap kelarutan kalsium dan magnesium email setelah perendaman gigi dengan spectrophotometer. Penelitian ini menggunakan minuman kemasan yang diperjualbelikan di pasar dan gigi post ekstraksi. Sedangkan pengukuran kelarutan kalsium dan magnesium dilakukan di Balai Besar Laboratorium Kesehatan Makassar. Jenis penelitian yang digunakan

adalah eksperimen. Penelitian ini menggunakan desain penelitian time series. Penelitian dimulai dengan menutup bagian akar gigi dengan menggunakan lakban. Setelah itu, gigi dimasukkan ke dalam masingmasing minuman yaitu dalam minuman coca cola dan pocari sweat.

Penelitian ini dilakukan untuk meneliti tentang kelarutan kalsium dan magnesium dimana kalsium adalah unsur yang paling banyak terdapat dalam email gigi sedangkan magnesium adalah unsur pendukung dalam email gigi. Terurainya ion kalsium dan magnesium memberikan efek negatif pada email gigi, dimulai dari demineralisasi email, terjadinya porositas email, berkurangnya ketahanan email, hingga terjadinya erosi gigi.

Lama waktu perendaman email gigi dalam penelitian ini yaitu selama 30 menit sampai pada hari keenam. Hal tersebut didasarkan pada, 1 menit adalah estimasi jumlah lama waktu terpaparnya email gigi dengan minuman yang dikonsumsi dalam setiap gelas/hari. Jadi interpretasi waktu dalam penelitian ini dapat menggambarkan konsums minuman dalam 180 hari (3 bulan).

Pemilihan minuman ringan yang mengandung asam juga diteliti pengaruhnya terhadap gigi. Makanan dan minuman yang mengandung asam dapat menyebabkan erosi pada email gigi salah satunya minuman yang mengandung asam folat (coca cola). Minuman isotonik juga dapat menyebabkan erosi gigi, karena berada antara rentan nilai $\mathrm{pH}$ 2,4-4,5.

Berdasarkan hasil penelitian yang dilakukan, menggambarkan bahwa coca cola dan pocari sweat mempunyai pengaruh terhadap kelarutan kalsium dan magnesium dalam kristal hidroksiapatit yang merupakan awal terjadinya demineralisasi email, walaupun masing-masing minuman tersebut memiliki pengaruh yang berbeda terhadap kelarutan kalsium dan magnesium. Salah satu tanda demineralisasi email ialah larutnya berbagai mineral, utamanya kalsium dan magnesium.

Pada tabel 3. dapat dilihat kelarutan kalsium dan magnesium dalam minuman coca cola dan pocari sweat berdasarkan waktu, terlihat bahwa kelarutan kalsium pada minuman coca cola yang telah direndam selama 30 menit sampai pada hari keenam sebesar 55,22 mg/L sedangkan kelarutan magnesium sebesar 12,46 mg/L. Namun ada sedikit perbedaan pada waktu perendamannya, tetapi tetap menggunakan minuman yang sama. Perbedaannya setelah gigi direndam dalam coca cola selama 30 menit selanjutnya gigi direndam kembali dalam aquades selama 15 menit sampai pada hari keenam, maka kelarutan kalsium yang terjadi sebesar 49,43 $\mathrm{mg} / \mathrm{L}$ sedangakn kelarutan 
magnesium sebesar 10,89 mg/L. Terlihat adanya perbedaan kelarutan kalsium dan magnesium antara gigi yang hanya direndam dalam minuman coca cola dengan gigi yang setelah direndam dalam minuman coca cola kemudian direndam kembali dalam aquades bahwa setelah gigi direndam kembali dalam aquades nilai kelarutannya lebih kecil dibandingkan dengan gigi yang tanpa direndam kembali dalam aquades.

Penelitian yang dilakukan oleh Sarifah (2013) juga menggambarkan hal yang sama, namun dengan mineral yang berbeda yaitu kelarutan fosfat sebesar 14,2 ppm selama 60 menit perendaman sedangkan untuk kelarutan magnesium yang dilakukan oleh Abdul (2012) mengatakam kelarutan magnesium sebesar 3,5 ppm.

Widodo (2010) juga mengatakan bahwa minuman karbonasi (coca cola) adalah salah satu minuman asam yang berpengaruh dalam terjadinya demineralisasi email gigi. Sedangkan untuk gigi yang direndam dalam minuman isotonik (pocari sweat) selama 30 menit sampai pada hari keenam mengalami kelarutan yang lebih kecil daripada minuman coca cola yaitu kelarutan kalsium sebesar $36,84 \mathrm{mg} / \mathrm{L}$ dan kelarutan megnesium sebesar $8,77 \mathrm{mg} / \mathrm{L}$. Tetapi gigi yang yang telah direndam dalam pocari sweat selama 30 menit lalu direndam kembali dalam aquades selama 15 menit sampai pada hari keenam lebih kecil mengalami kelarutan yaitu kelarutan kalsium sebesar 34,6 mg/L sedangkan kelarutan magnesium sebesar 7,28 mg/L.

Penelitian yang juga dilakukan oleh Wolff (2009) menyatakan bahwa minuman isotonik yang banyak dikonsumsi olahragawan dapat menimbulkan erosi email gigi, perubahan warna gigi, dan membuat gigi lebih sensitif. Asam sitrat yang merupakan komponen rasa dalam produk minuman olahraga ini dikaitkan dengan kerusakan gigi. Mereka yang mengkonsumsi minuman energi saat berolahraga sebaiknya tidak menyikat gigi selama beberapa saat setelah meminumnya. Wolff mengatakan setidaknya diperlukan waktu 30 menit agar lapisan email gigi tidak semakin terkikis. Dari data diatas dapat disimpulkan bahwa nilai kelarutan kalsium email gigi lebih tinggi daripada magnesium pada kedua jenis minuman tersebut

\section{KESIMPULAN}

Berdasarkan hasil penelitian
perbandingan kelarutan kalsium dan magnesium email gigi dapat disimpulkan bahwa nilai kelarutan ion kalsium email gigi lebih tinggi daripada ion magnesium baik pada minuman karbonasi maupun isotonik.

\section{SARAN}

Berdasarkan hasil yang diperoleh pada penelitian ini, maka dapat disarankan bahwa sebaiknya setelah meminum minuman yang mengandung asam, berkumurlah dengan air putih, untuk meminimalisir dampak yang diakibatkan dari minuman asam tersebut.

\section{DAFTAR PUSTAKA}

Achmad M.H. 2015. Karies dan Perawatan Pulpa pada Gigi Anak. Jakarta: Sagung Seto. p. 7-8.

Bamise C.T, Ogunboded E.O, Olusile A.O, Esan T.A. 2007. Erosive Potential of Soft Drinks in Nigeria. (Dent Journal): 2(2): 115-119. [serial online]. Available from: http://www.idosi.org/wims/2(2)07/9.pdf 
. Diakses pada tanggal 22 Maret 2016.

Fraunhofer J.A, Rogers M.M. 2004. Dissolution of dental enamel in soft drinks. (Dent Journal). 1(3): 125-130. [serial online]. Available from: http://www.umich.edu. Diakses pada tanggal 22 Maret 2016.

Mettler S, Rusch C, Colombani P.C. 2006. Osmolality and $\mathrm{pH}$ of sport and other drinks available in Switzerland. (Dent Journal): 54(3): 92-95. [serial online]. Available from: http://www.sgsm.ch. Diakses pada tanggal 22 Maret 2016.

Prasetya R.C. 2008. Perbandingan Jumlah Koloni Bakteri Saliva pada Anak-Anak Karies dan Non Karies Setelah Mengkonsumsi Minuman Berkarbonasi. (Dent Journal): 15(1): 65-70. [serial online]. Availabe from: http://www.jdentistry.ui.ac.id. Diakses pada tanggal 14 Februari 2016.
Prasetyo E.A. 2005. Keasaman Minuman Ringan Menurunkan Kekerasan Permukaan Gigi. (Dent Journal): 38(2): 60-63. [serial online]. Available from: $\quad$ http://journal.unair.ac.id. Diakses pada tanggal 14 Februari 2016.

Ruslan. 2014. Pengaruh Minuman Bersoda Terhadap Demineralisasi Email Gigi dengan Penambahan Natrium Fluorida. (Dent Journal). Vol 1: 61-65. [serial online]. Available from: http://ejournal.unpatti.ac.id. Diakses pada tanggal 16 Maret 2016.

Widodo R. 2008. Mengenal minuman ringan berkabonasi. [serial online]. Available from: $\quad$ http://www.untag-sby.ac.id. Diakses pada tanggal 14 Februari 2016. 